\title{
Slope Year for the U-Pb Dating Method and Its Applications
}

\section{Jie Yuan}

Key Laboratory of Earth and Planetary Physics, Institute of Geology and Geophysics, Chinese Academy of Science, Beijing, China

Email: yuanjie@mail.iggcas.ac.cn

Received 30 April 2015; accepted 23 May 2015; published 26 May 2015

Copyright (C) 2015 by author and Scientific Research Publishing Inc.

This work is licensed under the Creative Commons Attribution International License (CC BY).

http://creativecommons.org/licenses/by/4.0/

(c) (i) Open Access

\section{Abstract}

The slope year $t_{\text {slope }}$ for the $U$-Pb dating method is given as $t_{\text {slope }}=\frac{1}{\left(\lambda_{238}-\lambda_{235}\right)} \ln \frac{\lambda_{235}}{\lambda_{238}} k$, where $\lambda_{238}$ and $\lambda_{235}$ are the decay constants for ${ }^{238} \mathrm{U}$ and ${ }^{235} \mathrm{U}$, respectively, and $k$ is the slope of the tangent line at a point on either the Concordia or Discordia line. These two lines are determined by the initial ${ }^{206(7)} \mathrm{Pb}_{i}$ concentrations in minerals. If ${ }^{206} \mathrm{~Pb}_{i}={ }^{207} \mathrm{~Pb}_{i}=\mathbf{0}$, the line is the Concordia. However, if ${ }^{206} \mathrm{~Pb}_{i} \neq 0 \wedge{ }^{207} \mathrm{~Pb}_{i}=\mathbf{0}(\wedge$ is the logical operator "and", also known as the logical conjunction), ${ }^{206} \mathrm{~Pb}_{i}=\mathbf{0} \wedge{ }^{207} \mathrm{~Pb}_{i} \neq \mathbf{0}$ or ${ }^{206} \mathrm{~Pb}_{i} \neq \mathbf{0} \wedge{ }^{207} \mathrm{~Pb}_{i} \neq \mathbf{0}$, the line is Discordia. The Concordia line is of the form ${ }^{206} \mathrm{~Pb}_{p} /{ }^{238} \mathrm{U}_{p}=\left({ }^{207} \mathrm{~Pb}_{p} /{ }^{235} \mathrm{U}_{p}+1\right){ }^{\lambda_{238} / \lambda_{235}}-\mathbf{1}$ (where $\boldsymbol{p}$ stands for the present), while the Discordia line has the form ${ }^{206} \mathrm{~Pb}_{p} /{ }^{238} \mathrm{U}_{p}=k \times\left({ }^{207} \mathrm{~Pb}_{p} /{ }^{235} \mathrm{U}_{p}\right)+b$ (where $k$ and $b$ are the slope and intercept of the straight line, respectively).

\section{Keywords}

Slope Year, U-Pb Dating, Zircon, Mass Spectrum, Isotope, Initial Pb Isotope Concentration

\section{Introduction}

In nature, uranium has three radioactive isotopes: ${ }^{238} \mathrm{U}(99.2743 \%),{ }^{235} \mathrm{U}(0.7200 \%)$ and ${ }^{234} \mathrm{U}(0.0057 \%)$ [1] [2]. The former two isotopes decay in the forms:

$$
{ }_{92}^{238} \mathrm{U} \rightarrow{ }_{82}^{206} \mathrm{~Pb}+8{ }_{2}^{4} \mathrm{He}+6 \beta^{-}+Q
$$


and ${ }_{92}^{235} \mathrm{U} \rightarrow{ }_{82}^{207} \mathrm{~Pb}+7{ }_{2}^{4} \mathrm{He}+4 \beta^{-}+Q$,

where $Q$ is the heat, $\beta$ denotes the beta decay and He stands for the element Helium. The decay constants $\lambda$ for ${ }^{238} \mathrm{U}$ and ${ }^{235} \mathrm{U}$ are $\lambda_{238}=(1.55125 \pm 0.00672) \times 10^{-10}(1 \sigma) \quad a^{-1}$ and $\lambda_{235}=(9.8485 \pm 0.00083) \times 10^{-10}(1 \sigma) a^{-1}$, respectively [2]-[4].

These nuclear reactions occur in host minerals, such as zircon $\left(\mathrm{ZrSiO}_{4}\right)$, and are the basis of the U-Pb dating method in geology [5]-[8]. In a mineral, $\mathrm{Pb}$ and $\mathrm{U}$ isotopes obey the exponential decay law:

$$
\begin{aligned}
{ }^{206} \mathrm{~Pb}_{p} & ={ }^{206} \mathrm{~Pb}_{i}+{ }^{238} \mathrm{U}_{p}\left(\mathrm{e}^{\lambda_{235}}-1\right) \\
\text { and }{ }^{207} \mathrm{~Pb}_{p} & ={ }^{207} \mathrm{~Pb}_{i}+{ }^{235} \mathrm{U}_{p}\left(\mathrm{e}^{\lambda_{235^{t}}}-1\right),
\end{aligned}
$$

where the subscripts $i$ and $p$ represent the initial measurement time and the present, respectively, and $t$ is the age of the mineral [1] [6].

The coordinates $n\left({ }^{206} \mathrm{~Pb}_{p}\right) / n\left({ }^{238} \mathrm{U}_{p}\right)$ (n, the number of isotopes in the bracket) as the ordinate and $n\left({ }^{207} \mathrm{~Pb}_{p}\right) /$ $n\left({ }^{235} \mathrm{U}_{p}\right)$ ratios as the abscissa form the $\mathrm{Pb} / \mathrm{U}$ ratio diagram (Figure 1$)$. Samples formed $t$ years ago plot on either the Concordia or Discordia lines [9]-[12]. For instance, the classical Discordia line was discovered by Ahrens (1955) in Zimbabwe. Equation (1) divided by ${ }^{238} \mathrm{U}_{p}$ is $n\left({ }^{206} \mathrm{~Pb}_{p}\right) / n\left({ }^{238} \mathrm{U}_{p}\right)$ :

$$
\frac{{ }^{206} \mathrm{~Pb}_{p}}{{ }^{238} \mathrm{U}_{p}}=\frac{{ }^{206} \mathrm{~Pb}_{i}}{{ }^{238} \mathrm{U}_{p}}+\mathrm{e}^{\lambda_{238} t}-1 \text {. }
$$

Similarly for $n\left({ }^{207} \mathrm{~Pb}_{p}\right) / n\left({ }^{235} \mathrm{U}_{p}\right)$, we have

$$
\frac{{ }^{207} \mathrm{~Pb}_{p}}{{ }^{235} \mathrm{U}_{p}}=\frac{{ }^{207} \mathrm{~Pb}_{i}}{{ }^{235} \mathrm{U}_{p}}+\mathrm{e}^{\lambda_{235^{t}}}-1,
$$

from Equation (2).

To interpret the Discordia line, conventional theories have proposed: 1) this line was caused by $\mathrm{Pb}$ loss or $\mathrm{U}$ gain after formation of the host mineral [9] [11]-[17], 2) the upper intersection of the Discordia and Concordia lines represents the crystallization age of the mineral [12] and 3) the lower intersection of the Discordia and Concordia lines represents the metamorphic age of the mineral [14].

However, previous theories are not tenable when used in the following cases:

1) the lower intercept point is negative or

2) no upper intercept point exists.

For instance, in Zheng et al. (2012) (Figure 1), all zircons in YX1 from Yingxian lamproites were found to be discordant and yielded a lower intercept age of $-370 \pm 690 \mathrm{Ma}$. According to conventional theories, this age indicates that the samples will experience a metamorphic process in a distant age. In addition, in Zheng et al. (2012), all zircons in HBxa from Hebi basalt are also discordant, but yield no upper intercept age. According to conventional theories, these data indicate that the samples did not crystallize until the present. Apparently, the explanations do not conform to the objective facts: the samples are in front of scientists now. New studies should thus focus on resolving these discrepancies.

Herein, the slope years $t_{\text {slope }} s$ for the U-Pb dating method for the Concordia and Discordia lines are presented, and a method for estimating values for $t_{\text {slope }}$ from the experimental data is proposed. In addition, four examples are presented to illustrate the application of the proposed method.

\section{Methodology}

\subsection{Basic Assumptions}

In this study, the basic assumptions for the U-Pb dating method included the following:

a) The decay constants $\lambda_{238}$ and $\lambda_{235}$ are precisely determined. For instance, the decay constants in Jaffey et al. (1971) are of good quality and widely accepted. The number of citations of this paper is greater than 1200 (data from Web of Science);

b) Host minerals are not influenced by chemical reactions after formation. The minerals included apatite [18] [19], baddeleyite [20]-[25], monazite [26]-[33], tantalite [34]-[38], titanite [39]-[41], uraninite [42] [43] and zircon [44] [45], etc.; 


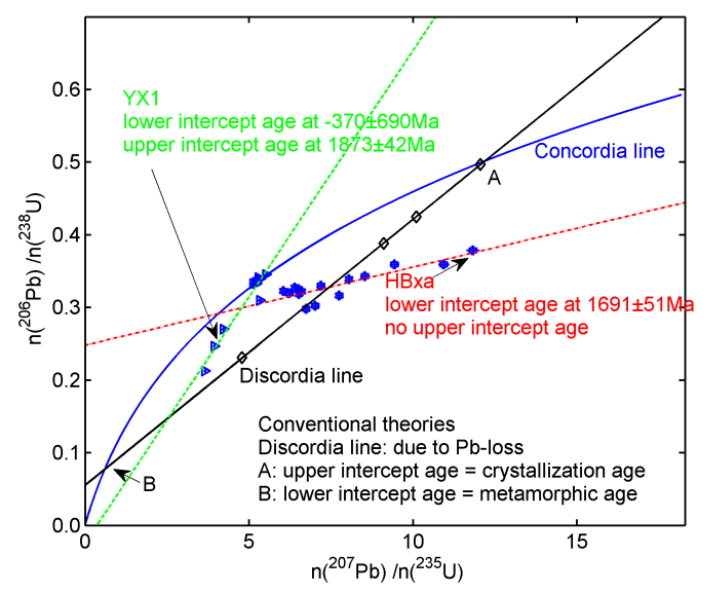

Figure 1. Pb/U ratio diagram. This diagram shows the predicament for conventional theories. The Concordia (blue, colour for online version) and classical Discordia (black) for Zimbabwe samples (black diamond points) (Ahrens, 1955) are illustrated. This Discordia and Concordia intercept at A and B, for which the meanings in conventional theories are shown in the lower-right corner. Two counter-examples to traditional theories are also shown: HBxa (hexagon points and red Discordia, Zheng et al. (2012)) and YX1 (right triangle points and green Discordia, Zheng et al. (2012)). See discussions in text.

c) Present ${ }^{206(7)} \mathrm{Pb}_{p}$ and ${ }^{235(8)} \mathrm{U}_{p}$ isotope concentrations in host minerals can be precisely measured using mass spectrometry (MS). Such MS instruments include sensitive high mass-resolution ion microprobe (SHRIMP) [46] [47], LaserProbe-inductively coupled plasma mass spectrometry (LP-ICPMS) [48] and Cameca IMS-series [44] [49], etc.

\subsection{Slope $k$ and Slope Year Tslope}

In mathematics, the variance on the ordinate is a function of the variance on the abscissa [50]. Therefore, $n\left({ }^{206} \mathrm{~Pb}_{p}\right) / n\left({ }^{238} \mathrm{U}_{p}\right)$ is a function of $n\left({ }^{207} \mathrm{~Pb}_{p}\right) / n\left({ }^{235} \mathrm{U}_{p}\right)$ in the $\mathrm{Pb} / \mathrm{U}$ diagram (Figure 2):

$$
{ }^{206} \mathrm{~Pb}_{p} /{ }^{238} \mathrm{U}_{p}=f\left({ }^{207} \mathrm{~Pb}_{p} /{ }^{235} \mathrm{U}_{p}\right) \text {. }
$$

The theoretical expressions for this function under different conditions are given in Section 2.4.

Next, the slope $k$ of the tangent line at point A on the general curve of Equation (5) was determined. The partial derivative of ${ }^{206} \mathrm{~Pb}_{p} /{ }^{238} \mathrm{U}_{p}$ (Equation (3)) with respect to $t$ is

$$
\frac{\partial\left(\frac{{ }^{206} \mathrm{~Pb}_{p}}{{ }^{238} \mathrm{U}_{p}}\right)}{\partial t}=\lambda_{238} \mathrm{e}^{\lambda_{238} t} \text {. }
$$

Similarly, we have

$$
\frac{\partial\left(\frac{{ }^{207} \mathrm{~Pb}_{p}}{{ }^{235} \mathrm{U}_{p}}\right)}{\partial t}=\lambda_{235} \mathrm{e}^{\lambda_{235} t}
$$

from Equation (4). Equation (6) divided by Equation (7) gives

$$
\frac{\partial\left(\frac{{ }^{206} \mathrm{~Pb}_{p}}{{ }^{238} \mathrm{U}_{p}}\right)}{\left.\frac{\partial\left(\frac{{ }^{206} \mathrm{~Pb}_{p}}{{ }^{207} \mathrm{~Pb}_{p}}\right.}{\partial t}\right)}=\frac{\partial\left(\frac{{ }^{238} \mathrm{U}_{p}}{{ }^{235}}\right)}{\partial\left(\frac{{ }^{207} \mathrm{~Pb}_{p}}{{ }^{235} \mathrm{U}_{p}}\right)}=\frac{\lambda_{238}}{\lambda_{235}} \mathrm{e}^{\left(\lambda_{238}-\lambda_{235}\right) t} .
$$




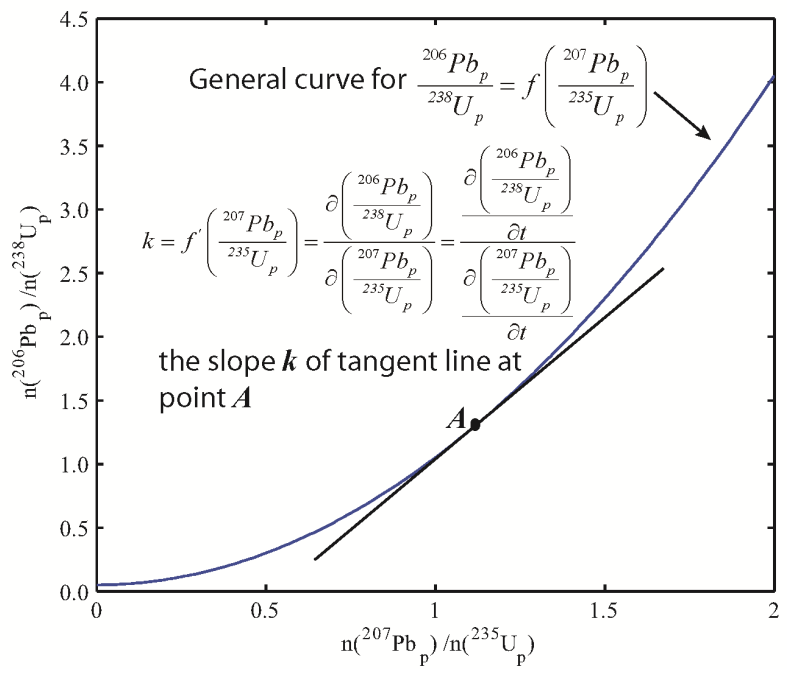

Figure 2. $\mathrm{Pb} / \mathrm{U}$ ratio diagram. The general curve (in blue) for ${ }^{206} \mathrm{~Pb}_{p} /{ }^{238} \mathrm{U}_{p}=f\left({ }^{207} \mathrm{~Pb}_{p} /{ }^{235} \mathrm{U}_{p}\right)$ and tangent line at point $\mathrm{A}$ on this curve are shown. The definition of the slope at this point is also given.

In this equation, the second part is the definition of the slope of the tangent line [50]:

$$
k=\frac{\partial\left(\frac{{ }^{206} \mathrm{~Pb}_{p}}{{ }^{238} \mathrm{U}_{p}}\right)}{\partial\left(\frac{{ }^{207} \mathrm{~Pb}_{p}}{{ }^{235} \mathrm{U}_{p}}\right)}=\frac{\lambda_{238}}{\lambda_{235}} \mathrm{e}^{\left(\lambda_{238}-\lambda_{235}\right) t} .
$$

This equation indicates that if $t$ is determined, the value of $k$ is a constant (Table 1 ) since $t \geq 0,0<k \leq 0.1575$. In addition, the slope monotonically decreases with increasing time $t$ (Figure 3 ).

If $k$ is determined (see Section 2.6), the slope year is given by rewriting Equation (9):

$$
t_{\text {slope }}=\frac{1}{\left(\lambda_{238}-\lambda_{235}\right)} \ln \frac{\lambda_{235}}{\lambda_{238}} k .
$$

\subsection{Initial ${ }^{206(7)} \mathrm{Pb}_{i}$ Concentrations in Minerals}

If the values for $t_{\text {slope }}{ }^{206(7)} \mathrm{Pb}_{p}$ and ${ }^{235(8)} \mathrm{U}_{p}$ are known, the initial ${ }^{206(7)} \mathrm{Pb}_{i}$ concentrations in minerals can be determined using the following:

$$
\begin{aligned}
{ }^{206} \mathrm{~Pb}_{i} & ={ }^{206} \mathrm{~Pb}_{p}-{ }^{238} \mathrm{U}_{p}\left(\mathrm{e}^{\lambda_{238^{t} \text { slope }}}-1\right) \\
\text { and }{ }^{207} \mathrm{~Pb}_{i} & ={ }^{207} \mathrm{~Pb}_{p}-{ }^{235} \mathrm{U}_{p}\left(\mathrm{e}^{\lambda_{235^{t_{\text {lope }}}}}-1\right) \text {, }
\end{aligned}
$$

which are derived from Equations (1) and (2). Clearly, the concentrations are greater than or equal to zero: ${ }^{206(7)} \mathrm{Pb}_{i} \geq 0$.

\subsection{Mathematical Expressions for the Concordia and Discordia Lines}

The initial ${ }^{206(7)} \mathrm{Pb}_{i}$ isotope concentrations determine the mathematical expressions for the general graph in Figure 2. This relationship can be demonstrated using assumed samples formed at the same time $t$ with specific initial conditions. Assume there are three samples (1, 2 and 3, Figure 4(a)) with

$$
{ }^{206} \mathrm{~Pb}_{i}={ }^{207} \mathrm{~Pb}_{i}=0
$$

and an additional three samples (4, 5 and 6, Figure 4(b)) with 


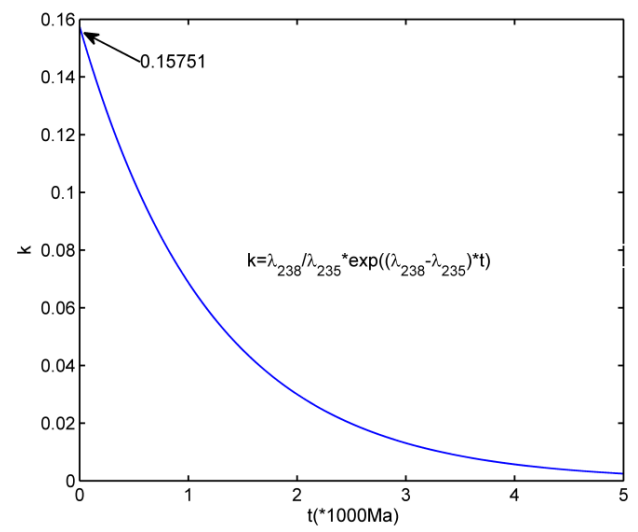

Figure 3. Plot of the slope $k$ versus time $t$.

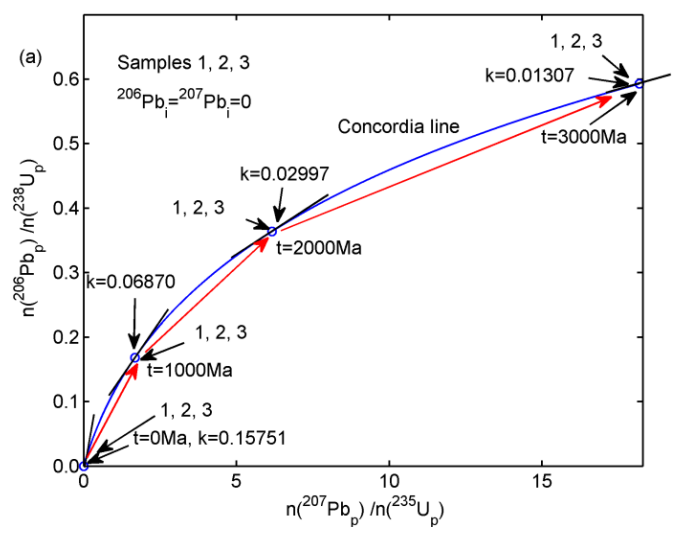

(a)

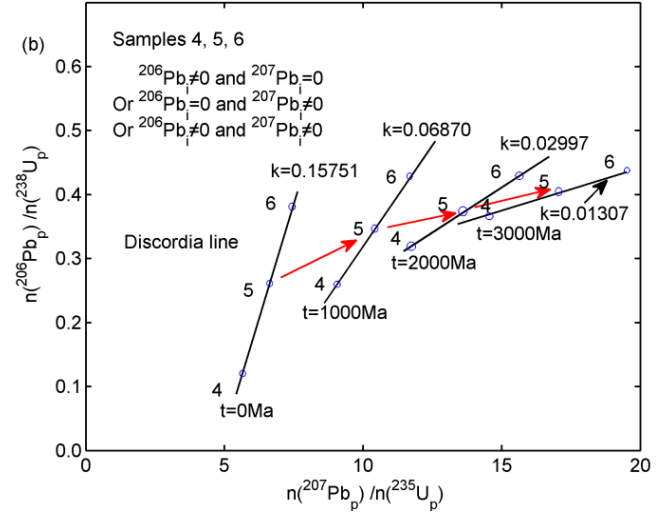

(b)

Figure 4. Histories of $\mathrm{Pb} / \mathrm{U}$ ratios (blue circle) for different samples on (a) Concordia and (b) Discordia. The red arrows indicate the direction of the evolution of each ratio.

Table 1. Values of the slope for specific years.

\begin{tabular}{cccccccccc}
\hline$t(\mathrm{Ma})$ & 0 & 100 & 1000 & 2000 & 3000 & 4000 \\
$k^{a}$ & 0.15751 & 0.14497 & 0.06870 & 0.02997 & 0.01307 & 0.00570 & 0.00249 \\
\hline
\end{tabular}

$a$, calculated from Equation (9)

$$
\begin{array}{llll}
\text { Or } & { }^{206} \mathrm{~Pb}_{i} \neq 0 & \wedge & { }^{207} \mathrm{~Pb}_{i}=0 \\
\text { Or } & { }^{206} \mathrm{~Pb}_{i}=0 & \wedge & { }^{207} \mathrm{~Pb}_{i} \neq 0 \\
\text { Or } & { }^{206} \mathrm{~Pb}_{i} \neq 0 & \wedge & { }^{207} \mathrm{~Pb}_{i} \neq 0
\end{array}
$$

The mathematical expressions are given by solving the first-order differential Equation (9) using Equations (3) and (4):

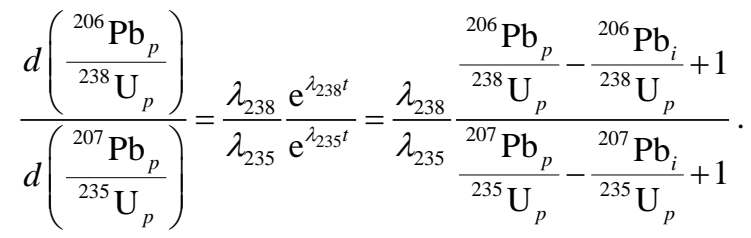

The solution to this equation is different for each set of samples.

a) For samples 1, 2 and 3, rewriting Equation (15) using Equation (13) gives 


$$
\frac{d\left(\frac{{ }^{206} \mathrm{~Pb}_{p}}{{ }^{238} \mathrm{U}_{p}}\right)}{\frac{{ }^{206} \mathrm{~Pb}_{p}}{{ }^{238} \mathrm{U}_{p}}+1}=\frac{\lambda_{238}}{\lambda_{235}} \frac{d\left(\frac{{ }^{207} \mathrm{~Pb}_{p}}{{ }^{235} \mathrm{U}_{p}}\right)}{\frac{{ }^{207} \mathrm{~Pb}_{p}}{{ }^{235} \mathrm{U}_{p}}+1} .
$$

The general solution of Equation (16) is

$$
\ln \left(\frac{{ }^{206} \mathrm{~Pb}_{\mathrm{p}}}{{ }^{238} \mathrm{U}_{p}}+1\right)=\ln \left(\frac{{ }^{207} \mathrm{~Pb}_{\mathrm{p}}}{{ }^{235} \mathrm{U}_{p}}+1\right)^{\frac{\lambda_{238}}{\lambda_{235}}}+C .
$$

Since the concentrations of ${ }^{206} \mathrm{~Pb}_{i}$ and ${ }^{207} \mathrm{~Pb}_{i}$ are both zero at $t=0$, the result is $0=0+C$; thus, $C=0$. Therefore,

$$
\ln \left(\frac{{ }^{206} \mathrm{~Pb}_{p}}{{ }^{238} \mathrm{U}_{p}}+1\right)=\ln \left(\frac{{ }^{207} \mathrm{~Pb}_{p}}{{ }^{235} \mathrm{U}_{p}}+1\right)^{\frac{\lambda_{238}}{\lambda_{235}}}
$$

or

$$
\frac{{ }^{206} \mathrm{~Pb}_{p}}{{ }^{238} \mathrm{U}_{p}}=\left(\frac{{ }^{207} \mathrm{~Pb}_{p}}{{ }^{235} \mathrm{U}_{p}}+1\right){ }^{\frac{\lambda_{238}}{\lambda_{235}}}-1,
$$

which is the expression for the Concordia line.

b) For samples 4, 5 and 6, because of the existence of the variances in ${ }^{206} \mathrm{~Pb}_{i} /{ }^{238} \mathrm{U}_{p}$ and/or ${ }^{207} \mathrm{~Pb}_{i} /{ }^{235} \mathrm{U}_{p}$ (Equation (14)), Equation (15) is not an elementary function and the solution to it cannot be obtained using elementary integral calculus.

This difficulty can be overcome in the following manner. Consider a geological body (containing samples 4, 5 and 6) with continuous ${ }^{206} \mathrm{~Pb}_{i},{ }^{207} \mathrm{~Pb}_{i},{ }^{238} \mathrm{U}_{i}$ and ${ }^{235} \mathrm{U}_{i}$ distributions. Then ${ }^{206} \mathrm{~Pb}_{i} /{ }^{238} \mathrm{U}_{i}$ and ${ }^{207} \mathrm{~Pb}_{i} /{ }^{235} \mathrm{U}_{i}$ in the system are continuous variables [50]. Looking back to the original differential Equation (9):

$$
\frac{\partial\left(\frac{{ }^{206} \mathrm{~Pb}_{p}}{{ }^{238} \mathrm{U}_{p}}\right)}{\partial\left(\frac{{ }^{207} \mathrm{~Pb}_{p}}{{ }^{235} \mathrm{U}_{p}}\right)}=k .
$$

Since $k$ is a constant when $t$ is given (Table 1 ), the solution to this equation is

$$
\frac{{ }^{206} \mathrm{~Pb}_{p}}{{ }^{238} \mathrm{U}_{p}}=k \frac{{ }^{207} \mathrm{~Pb}_{p}}{{ }^{235} \mathrm{U}_{p}}+b,
$$

where $k$ and $b$ are the slope and intercept of the line, respectively. This equation shows that the general curve in Figure 2 is a straight line, i.e. the Discordia line.

Equation (21) is consistent with the initial condition (Equation (14)). If $k=0.15751$ (at $t=0$ ) is applied:

$$
\frac{{ }^{206} \mathrm{~Pb}_{i}}{{ }^{238} \mathrm{U}_{i}}=0.15751 \times \frac{{ }^{207} \mathrm{~Pb}_{i}}{{ }^{235} \mathrm{U}_{i}}+b_{i} .
$$

This equation indicates that 1 ) in the geological system, ${ }^{206} \mathrm{~Pb}_{i}{ }^{238} \mathrm{U}_{i}$ monotonically increases with increasing ${ }^{207} \mathrm{~Pb}_{i}{ }^{235} \mathrm{U}_{i}$ from samples 4 to 5 to 6 (Figure 4(b)) and 2) these two ratios for the three samples cannot simultaneously be zero.

\subsection{Histories of $\mathrm{Pb} / \mathrm{U}$ Ratios on the Concordia and Discordia Lines}

The ${ }^{206(7)} \mathrm{Pb}_{i}$ also determines the histories of the $\left({ }^{207} \mathrm{~Pb}_{p} /{ }^{235} \mathrm{U}_{p},{ }^{206} \mathrm{~Pb}_{p} /{ }^{238} \mathrm{U}_{p}\right)$ data points on the Concordia 
and Discordia lines. In Figure 4, the histories are shown for

a) samples 1, 2 and 3 (Figure 4(a)), for which when $t=0$, the $\left({ }^{207} \mathrm{~Pb}_{p} /{ }^{235} \mathrm{U}_{p},{ }^{206} \mathrm{~Pb}_{p} /{ }^{238} \mathrm{U}_{p}\right)$ points plot on the origin $(0,0)$ where the Concordia line begins (Equation (19)). As time increases, the slope of the curve decreases from 0.15751 (0 Ma) to 0.06870 (1000 Ma) to 0.02997 (2000 Ma) and finally to 0.01307 (3000 Ma) (Table 1) and

b) samples 4, 5 and 6 (Figure 4(b)), for which when $t=0$ the $\left({ }^{207} \mathrm{~Pb}_{p} /{ }^{235} \mathrm{U}_{p},{ }^{206} \mathrm{~Pb}_{p} /{ }^{238} \mathrm{U}_{p}\right)$ points plot on a straight line with slope 0.15751 (Equation (22)). As time increases, the three

$\left({ }^{207} \mathrm{~Pb}_{p} /{ }^{235} \mathrm{U}_{p},{ }^{206} \mathrm{~Pb}_{p} /{ }^{238} \mathrm{U}_{p}\right)$ points plot on discordant lines with different slopes, and the slope of each line decreases from 0.15751 ( 0 Ma) to 0.06870 (1000 Ma) to 0.02997 (2000 Ma) and finally to 0.01307 (3000 Ma) (Table 1).

\subsection{Methods for Determining $\mathrm{k}$ from Experimental Data}

For $n\left({ }^{206} \mathrm{~Pb}_{\mathrm{p}} /{ }^{238} \mathrm{U}_{p},{ }^{207} \mathrm{~Pb}_{\mathrm{p}} /{ }^{235} \mathrm{U}_{p}\right) \quad(i=1,2,3, \cdots, n)$ data points obtained from a mass spectrum, the $k$ values are given as follows.

a) If the $n$ data points plot on the Concordia line (Figure 4(a)), using Equation (19), the slope of the $i$ th data point is

$$
k_{\text {Concordia }, i}=\frac{d\left(\frac{{ }^{206} \mathrm{~Pb}_{p}}{{ }^{238} \mathrm{U}_{p}}\right)}{d\left(\frac{{ }^{207} \mathrm{~Pb}_{p}}{{ }^{235} \mathrm{U}_{p}}\right)}=\frac{\left.d\left(\frac{{ }^{207} \mathrm{~Pb}_{p}}{{ }^{235} \mathrm{U}_{p}}+1\right)^{\frac{\lambda_{238}}{\lambda_{235}}}-1\right)}{d\left(\frac{{ }^{207} \mathrm{~Pb}_{p}}{{ }^{235} \mathrm{U}_{p}}\right)}=0.15751 \times\left(\left(\frac{{ }^{207} \mathrm{~Pb}_{p}}{{ }^{235} \mathrm{U}_{p}}\right)+1\right)_{i}^{-0.84249},
$$

where $\lambda_{238} / \lambda_{235}=0.15751$. The mean slope for all the $n$ points is then

$$
k_{\text {Concordia }}=\frac{\sum_{i=1}^{n} k_{\text {Concordia }, i}}{n} .
$$

b) If the $n$ data points plot on the Discordia line (Figure 4(b)), the slope can be determined using the least squares method [51]. This method gives a linear function for the points:

$$
y=k_{\text {Discordia }} \times x+b,
$$

where

$$
k_{\text {Discordia }}=\frac{\sum_{i=1}^{n}\left(\left(\frac{{ }^{207} \mathrm{~Pb}_{p}}{{ }^{235} \mathrm{U}_{p}}\right)_{i}-\text { Mean }\left(\frac{{ }^{207} \mathrm{~Pb}_{p}}{{ }^{235} \mathrm{U}_{p}}\right)\right)\left(y_{i}-\text { Mean }(y)\right)}{\sum_{i=1}^{n}\left(\left(\frac{{ }^{207} \mathrm{~Pb}_{p}}{{ }^{235} \mathrm{U}_{p}}\right)_{i}-\text { Mean }\left(\frac{{ }^{207} \mathrm{~Pb}_{p}}{{ }^{235} \mathrm{U}_{p}}\right)\right)^{2}}
$$

and Mean $\left({ }^{207} \mathrm{~Pb}_{p} /{ }^{235} \mathrm{U}_{p}\right)=\sum_{i=1}^{n}\left({ }^{207} \mathrm{~Pb}_{p} /{ }^{235} \mathrm{U}_{p}\right)_{i} / n$, Mean $(y)=\sum_{i=1}^{n} y_{i} / n$ and $y_{i}=k_{\text {Discordia }} \times\left({ }^{207} \mathrm{~Pb}_{p} /{ }^{235} \mathrm{U}_{p}\right)_{i}+b$. See proofs for $k_{\text {Discordia }}$ in Appendix A.

\subsection{Error Propagation}

For a function $f=f(x, y, z, \cdots)$, where $x, y$ and $z$ are independent variables, the error $(1 \sigma)$ is given by

$$
\sigma_{f}=\sqrt{\left(\frac{\partial f}{\partial x}\right)^{2} \sigma_{x}^{2}+\left(\frac{\partial f}{\partial y}\right)^{2} \sigma_{y}^{2}+\left(\frac{\partial f}{\partial z}\right)^{2} \sigma_{z}^{2}+\cdots},
$$

where $\sigma_{x}, \sigma_{y}$ and $\sigma_{z}$ are the standard errors for $x, y$ and $z$, respectively [51]. 
According to Equation (27), the standard error for $t_{\text {slope }}$ (Equation (10)) is

$$
\sigma_{t_{\text {slope }}}=\sqrt{\left(\frac{\partial t}{\partial k}\right)^{2} \sigma_{k}^{2}+\left(\frac{\partial t}{\partial \lambda_{238}}\right)^{2} \sigma_{\lambda_{238}}^{2}+\left(\frac{\partial t}{\partial \lambda_{235}}\right)^{2} \sigma_{\lambda_{235}}^{2}}
$$

or

$\sigma_{t_{\text {slope }}}=\sqrt{\left(\frac{1}{\left(\lambda_{238}-\lambda_{235}\right)} \frac{\lambda_{238}}{\lambda_{235}} \frac{1}{k}\right)^{2} \sigma_{k}^{2}+\left(\frac{1}{\left(\lambda_{238}-\lambda_{235}\right)^{2}} \ln \left(\frac{\lambda_{235}}{\lambda_{238}} k\right)+\frac{1}{\left(\lambda_{238}-\lambda_{235}\right)} \frac{1}{\lambda_{238}}\right)^{2} \sigma_{\lambda_{238}}^{2}+\left(\frac{1}{\left(\lambda_{238}-\lambda_{235}\right)^{2}} \ln \left(\frac{\lambda_{235}}{\lambda_{238}} k\right)+\frac{1}{\left(\lambda_{238}-\lambda_{235}\right)} \frac{1}{\lambda_{235}}\right)^{2} \sigma_{\lambda_{235}}^{2}}$,

where $\sigma_{\lambda_{235}}=6.7167 \times 10^{-13} a^{-1}$ and $\sigma_{\lambda_{238}}=8.3321 \times 10^{-14} a^{-1}$ [3] and $\sigma_{k}$ is the standard error of the slope. Then the values for $\sigma_{k}$ are given as follows.

a) For concordant data, the standard error of the ith slope (Equation (23)) is

$$
\sigma_{k, \text { Concordia }, i}=d k_{\text {Concordia }, i}=0.13270 \times\left(\left(\frac{{ }^{207} \mathrm{~Pb}_{p}}{{ }^{235} \mathrm{U}_{p}}\right)_{i}+1\right)^{-1.84249} \sigma_{\left(\frac{207}{{ }^{235} \mathrm{~Pb}_{p}}\right)_{i}},
$$

and the standard error of the mean slope (Equation (24)) is

$$
\sigma_{k, \text { Concordia }}=\sqrt{\frac{\sum_{i=1}^{n}\left(\sigma_{k \text { Concordia }, i}\right)^{2}}{n} .}
$$

b) For discordant data, the standard error of $k$ in Equation (26) is

$$
\sigma_{k, \text { Discordia }}=\sqrt{\frac{1}{n-2} \times\left(\frac{\sum_{i=1}^{n}\left(\left(\frac{{ }^{206} \mathrm{~Pb}_{p}}{{ }^{238} \mathrm{U}_{p}}\right)_{i}-\text { Mean }\left(\frac{{ }^{206} \mathrm{~Pb}_{p}}{{ }^{238} \mathrm{U}_{p}}\right)\right)^{2}}{\sum_{i=1}^{n}\left(\left(\frac{{ }^{207} \mathrm{~Pb}_{p}}{{ }^{235} \mathrm{U}_{p}}\right)_{i}-\text { Mean }\left(\frac{{ }^{207} \mathrm{~Pb}_{p}}{{ }^{235} \mathrm{U}_{p}}\right)\right)^{2}}-\frac{\left[\sum_{i=1}^{n}\left(\left(\frac{{ }^{207} \mathrm{~Pb}_{p}}{{ }^{235} \mathrm{U}_{p}}\right)_{i}-\text { Mean }\left(\frac{{ }^{207} \mathrm{~Pb}_{p}}{{ }^{235} \mathrm{U}_{p}}\right)\right)\left(\left(\frac{{ }^{206} \mathrm{~Pb}_{p}}{{ }^{238} \mathrm{U}_{p}}\right)_{i}-\text { Mean }\left(\frac{{ }^{206} \mathrm{~Pb}_{p}}{{ }^{238} \mathrm{U}_{p}}\right)\right)\right]^{2}}{\left[\sum_{i=1}^{n}\left(\left(\frac{{ }^{207} \mathrm{~Pb}_{p}}{{ }^{235} \mathrm{U}_{p}}\right)-\text { Mean }\left(\frac{{ }^{207} \mathrm{~Pb}_{p}}{{ }^{235} \mathrm{U}_{p}}\right)\right)^{2}\right]^{2}}\right.} .
$$

See proofs of this equation in Appendix A.

According to Equation (27), the standard error for ${ }^{206(207)} \mathrm{Pb}_{i}$ (Equations (11) and (12)) is

$$
\begin{aligned}
& \sigma_{m_{\mathrm{Pb}_{i}}}=\sqrt{\left(\frac{\partial^{m} \mathrm{~Pb}_{i}}{\partial^{n} \mathrm{U}_{p}}\right)^{2} \sigma_{{ }^{\mathrm{U}_{p}}}^{2}+\left(\frac{\partial^{m} \mathrm{~Pb}_{i}}{\partial \lambda_{n}}\right)^{2} \sigma_{\lambda_{n}}^{2}+\left(\frac{\partial^{m} \mathrm{~Pb}_{i}}{\partial t_{\text {slope }}}\right)^{2} \sigma_{t_{\text {slope }}}^{2}+\left(\frac{\partial^{m} \mathrm{~Pb}_{i}}{\partial^{m} \mathrm{~Pb}_{p}}\right)^{2} \sigma_{m_{\mathrm{Pb}_{p}}}^{2}} \\
& \sigma_{{ }_{m} \mathrm{~Pb}_{i}}=\sqrt{\left(\mathrm{e}^{\lambda_{n} t_{\text {lope }}}-1\right)^{2} \sigma_{{ }_{\mathrm{U}_{p}}}^{2}+\left({ }^{n} \mathrm{U}_{p} t_{\text {slope }} \mathrm{e}^{\lambda_{n} t_{\text {slope }}}\right)^{2} \sigma_{\lambda_{n}}^{2}+\left({ }^{n} \mathrm{U}_{p} \lambda_{n} \mathrm{e}^{\lambda_{n} t_{\text {slope }}}\right)^{2} \sigma_{t_{\text {slope }}}^{2}+\sigma_{m_{\mathrm{Pb}_{p}}}^{2}}
\end{aligned}
$$

where $m$ and $n$ stand for 206(7) and 235(8) respectively, $\sigma_{m_{\mathrm{Ph}}}$ and $\sigma_{n_{U}}$ are taken from experimental data, $\sigma_{t_{\text {slope }}}$ is obtained using Equation (28) and $\sigma_{\lambda_{235}}=6.7167 \times 10^{-1 B}$ and $a^{-1}$ a $\sigma_{\lambda_{238}}=8.3321 \times 10^{-14} a^{-1}[3]$.

\section{Applications}

To demonstrate the validity of our work, four examples are illustrated (Table 2 and Figure 5). Table 2 includes original $\mathrm{Pb} / \mathrm{U}$ isotope ratios from the published literature along with the slope years (i.e. $\mathrm{U}-\mathrm{Pb}$ ages) when the samples were formed.

The first example comes from Qinghu granite in the Nanling Range, South China [44]. The $\mathrm{Pb} / \mathrm{U}$ ratios in this granite are the concordant type (Figure 5(a)) [44]. The slope and slope year were calculated using Equations (24) and (10), respectively, and found to be $k_{\text {Concordia }}=0.13792 \pm 0.00025$ and $t_{\text {slope }}=160 \pm 2$ Ma (Table 2), which are in good agreement with values reported by Li et al., 2009. 


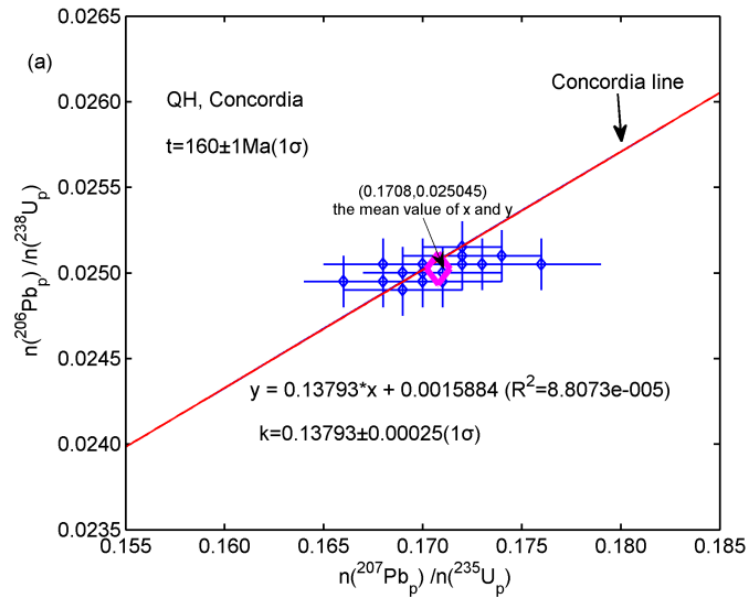

(a)

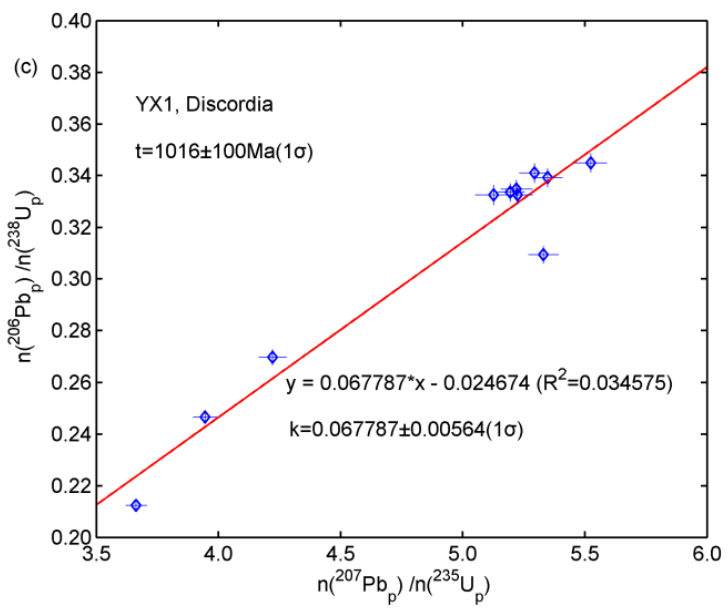

(c)

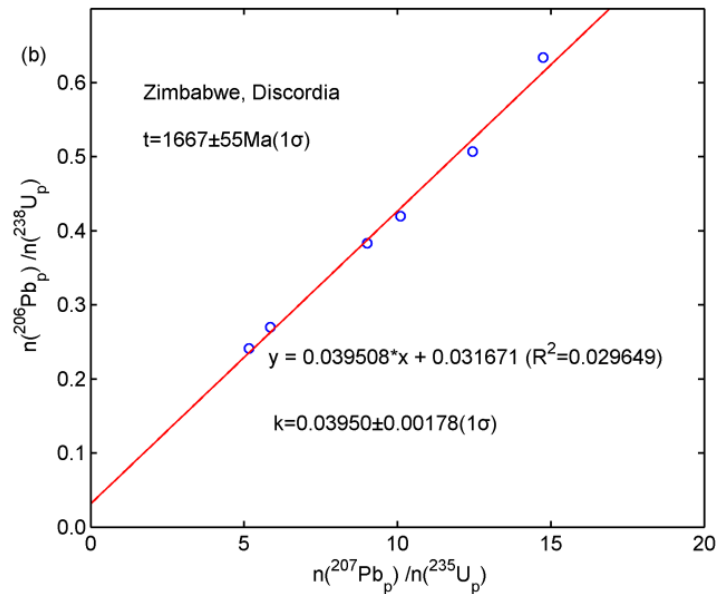

(b)

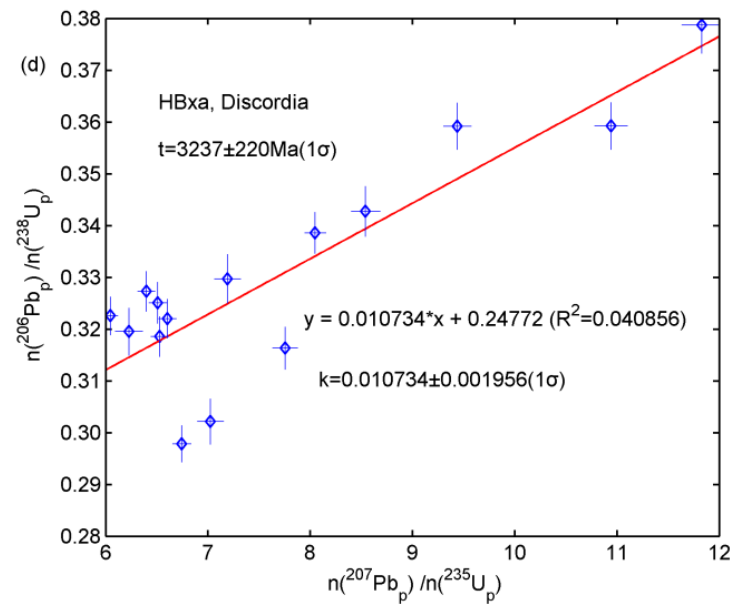

(d)

Figure 5. Present slope years (with $1 \sigma$ error) for (a) Qinghu granite, (b) a Zimbabwe uranium deposit, (c) Yingxian amphibolites and (d) Hebi amphibolites. All data points except Zimbabwe are plotted with $1 \sigma$ error bars. The norms of the residuals $\left(R^{2}\right)$ for the least squares fits are illustrated, and the slopes (with $1 \sigma$ errors) are given. In (a), the red diamond indicates the mean value for all the measured data and the tangent line at this point coincides with the Concordia line.

The $k$ and $t_{\text {slope }}$ values for the three discordant examples described in the introduction were also calculated using Equations (26) and (10), respectively. For the Zimbabwe uranium deposit (Figure 5(b)), the slope was $k_{\text {Discordia }}=0.03950 \pm 0.00178$ and slope year was $t_{\text {slope }}=1668 \pm 55$ Ma. For amphibolites in the Yingxian lamproite (YX1, Figure 5(c)), the slope was $k_{\text {Discordia }}=0.06779 \pm 0.00564$ and slope year was $t_{\text {slope }}=1016 \pm 100 \mathrm{Ma}$. For Hebi amphibolites (HBxa, Figure 5(d)), the slope was $k_{\text {Discordia }}=0.010734 \pm 0.00196$ and slope year was $t_{\text {slope }}=3237 \pm 220 \mathrm{Ma}$.

\section{Conclusion}

A method for determining the slope year for the U-Pb dating method and initial ${ }^{206(7)} \mathrm{Pb}$ concentrations in samples was described. It was also found that if no ${ }^{206(7)} \mathrm{Pb}$ isotopes are initially present in minerals, the $\mathrm{Pb} / \mathrm{U}$ ratios plot on the Concordia line. On the other hand, if ${ }^{206(7)} \mathrm{Pb}$ isotopes are initially present in minerals, the $\mathrm{Pb} / \mathrm{U}$ ratios plot on the Discordia line. Therefore, the Discordia line is not the result of $\mathrm{Pb}$ loss or $\mathrm{U}$ gain. Furthermore, methods for determining the slope year using experimental data were also proposed and applied to data on four samples previously described in the literature. These results demonstrate that our approach is useful for geological research. 
Table 2. Values for ${ }^{206} \mathrm{~Pb} /{ }^{238} \mathrm{U},{ }^{207} \mathrm{~Pb} /{ }^{235} \mathrm{U}$, the slope $(k)$ and the slope year $\left(t_{\text {slope }}\right)$ of zircons in different geological bodies. The $\mathrm{Pb} / \mathrm{U}$ isotope ratios in the Qinghu granite (07QH-1), a Zimbabwe uranium deposit, Yingxian amphibolites (YX1) and Hebi amphibolites (HBxa) are taken from Li et al. (2009), Ahrens, (1955), Zheng et al. (2012) and Zheng et al. (2012), respectively.

\begin{tabular}{|c|c|c|c|c|c|c|c|c|c|}
\hline \multirow{2}{*}{ Type } & \multicolumn{6}{|c|}{ Experiments } & \multicolumn{3}{|c|}{ Present Results } \\
\hline & Locations & Samples & ${ }^{206} \mathrm{~Pb} /{ }^{238} \mathrm{U}$ & $1 \sigma$ & ${ }^{207} \mathrm{~Pb} /{ }^{235} \mathrm{U}$ & $1 \sigma$ & Item & Value & $1 \sigma$ \\
\hline \multirow[t]{21}{*}{ Concordia } & 07QH-1 & 1 & 0.0250 & 0.0003 & 0.171 & 0.003 & $k$ & 0.13792 & 0.00025 \\
\hline & & 2 & 0.0253 & 0.0003 & 0.172 & 0.002 & $t_{\text {slope }}$ & 160 & $2 \mathrm{Ma}$ \\
\hline & & 3 & 0.0252 & 0.0003 & 0.172 & 0.003 & & & \\
\hline & & 4 & 0.0250 & 0.0003 & 0.170 & 0.003 & & & \\
\hline & & 5 & 0.0252 & 0.0003 & 0.172 & 0.002 & & & \\
\hline & & 6 & 0.0249 & 0.0003 & 0.171 & 0.003 & & & \\
\hline & & 7 & 0.0251 & 0.0003 & 0.173 & 0.002 & & & \\
\hline & & 8 & 0.0251 & 0.0003 & 0.168 & 0.003 & & & \\
\hline & & 9 & 0.0251 & 0.0003 & 0.176 & 0.003 & & & \\
\hline & & 10 & 0.0251 & 0.0003 & 0.170 & 0.003 & & & \\
\hline & & 11 & 0.0251 & 0.0003 & 0.172 & 0.002 & & & \\
\hline & & 12 & 0.0248 & 0.0003 & 0.169 & 0.003 & & & \\
\hline & & 13 & 0.0251 & 0.0003 & 0.172 & 0.003 & & & \\
\hline & & 14 & 0.0250 & 0.0003 & 0.170 & 0.002 & & & \\
\hline & & 15 & 0.0250 & 0.0003 & 0.169 & 0.002 & & & \\
\hline & & 16 & 0.0249 & 0.0003 & 0.166 & 0.002 & & & \\
\hline & & 17 & 0.0250 & 0.0003 & 0.171 & 0.002 & & & \\
\hline & & 18 & 0.0249 & 0.0003 & 0.170 & 0.002 & & & \\
\hline & & 19 & 0.0249 & 0.0003 & 0.168 & 0.002 & & & \\
\hline & & 20 & 0.0252 & 0.0003 & 0.174 & 0.002 & & & \\
\hline & & Mean & 0.0250 & 0.0003 & 0.171 & 0.0025 & & & \\
\hline \multirow[t]{6}{*}{ Discordia } & Zimbabwe & Monazite(Manitoba) & 0.634 & 0.000 & 14.75 & 0.00 & $k$ & 0.03950 & 0.00178 \\
\hline & & Monazite(Ebonite) & 0.507 & 0.000 & 12.45 & 0.00 & $t_{\text {slope }}$ & 1667 & $55 \mathrm{Ma}$ \\
\hline & & Monazite(Jack Tin) & 0.420 & 0.000 & 10.10 & 0.00 & & & \\
\hline & & Monazite(Irumi) & 0.383 & 0.000 & 9.02 & 0.00 & & & \\
\hline & & Uraainite(Manitoba) & 0.270 & 0.000 & 5.85 & 0.00 & & & \\
\hline & & Monazite(Antsirabe) & 0.241 & 0.000 & 5.16 & 0.00 & & & \\
\hline \multirow[t]{6}{*}{ Discordia } & YX1 & 1 & 0.33464 & 0.00363 & 5.22129 & 0.06472 & $k$ & 0.06779 & 0.00564 \\
\hline & & 2 & 0.34491 & 0.00368 & 5.52554 & 0.06520 & $t_{\text {slope }}$ & 1016 & $100 \mathrm{Ma}$ \\
\hline & & 3 & 0.33249 & 0.00385 & 5.12718 & 0.07519 & & & \\
\hline & & 4 & 0.33347 & 0.00352 & 5.19461 & 0.05960 & & & \\
\hline & & 5 & 0.21231 & 0.00226 & 3.66393 & 0.04298 & & & \\
\hline & & 6 & 0.33912 & 0.00358 & 5.34786 & 0.06130 & & & \\
\hline
\end{tabular}




\section{Continued}

\begin{tabular}{|c|c|c|c|c|c|c|c|c|c|}
\hline & & 7 & 0.33246 & 0.00353 & 5.22593 & 0.06103 & & & \\
\hline & & 8 & 0.24655 & 0.00268 & 3.94621 & 0.04940 & & & \\
\hline & & 9 & 0.30931 & 0.00328 & 5.33072 & 0.06161 & & & \\
\hline & & 10 & 0.26968 & 0.00309 & 4.22308 & 0.05705 & & & \\
\hline & & 11 & 0.34094 & 0.00374 & 5.29417 & 0.06276 & & & \\
\hline \multirow[t]{15}{*}{ Discordia } & Hbxa & 1 & 0.31857 & 0.00389 & 6.52978 & 0.08636 & $k$ & 0.010734 & 0.001956 \\
\hline & & 2c & 0.37868 & 0.00542 & 11.83149 & 0.19556 & $t_{\text {slope }}$ & 3237 & $220 \mathrm{Ma}$ \\
\hline & & $2 \mathrm{r}$ & 0.35917 & 0.00452 & 9.43864 & 0.13599 & & & \\
\hline & & 3c & 0.32201 & 0.00375 & 6.60397 & 0.08699 & & & \\
\hline & & $3 r$ & 0.32726 & 0.00388 & 6.39918 & 0.08482 & & & \\
\hline & & 4 & 0.35923 & 0.00457 & 10.94269 & 0.15946 & & & \\
\hline & & 5 & 0.33858 & 0.00402 & 8.05032 & 0.10509 & & & \\
\hline & & 6 & 0.32256 & 0.00368 & 6.04709 & 0.07394 & & & \\
\hline & & 7 & 0.32507 & 0.00396 & 6.51079 & 0.08888 & & & \\
\hline & & 8 & 0.29783 & 0.00355 & 6.74590 & 0.09045 & & & \\
\hline & & 9 & 0.32970 & 0.00477 & 7.19338 & 0.12913 & & & \\
\hline & & 10 & 0.34275 & 0.00486 & 8.54210 & 0.14216 & & & \\
\hline & & 11 & 0.31630 & 0.00412 & 7.75610 & 0.12353 & & & \\
\hline & & 12 & 0.30213 & 0.00442 & 7.02483 & 0.12968 & & & \\
\hline & & 13 & 0.31948 & 0.00461 & 6.22754 & 0.13341 & & & \\
\hline
\end{tabular}

\section{Acknowledgements}

This work was supported by the National Natural Science Foundation of China (Grant Nos. 41303047, 90914010 and 41020134003$)$.

\section{References}

[1] Rutherford, E. and Soddy, F. (1903) The Radioactivity of Uranium. Philosophical Magazine, 5, 25-30, 441-445.

[2] Audi, G., Bersillon, O., Blachot, J. and Wapstra, A.H. (2003) The Nubase Evaluation of Nuclear and Decay Properties. Nuclear Physics A, 729, 3-128. http://dx.doi.org/10.1016/j.nuclphysa.2003.11.001

[3] Jaffey, A.H., Flynn, K.F., Glendenin, L.E., Bentley, W.C. and Essling, A.M. (1971) Precision Measurement of HalfLives and Specific Activities of 235U and 238U. Physical Review C, 4, 1889-1906. http://dx.doi.org/10.1103/PhysRevC.4.1889

[4] Pomme, S., Garcia-Torano, E., Sibbens, G., Richter, S., Wellum, R., Stolarz, A., et al. (2008) U-234/U-235 Activity Ratios as a Probe for the U-238/U-235 Half-Life Ratio. Journal of Radioanalytical and Nuclear Chemistry, 277, $207-$ 210. http://dx.doi.org/10.1007/s10967-008-0731-6

[5] Baker, T., Perkins, C., Blake, K.L. and Williams, P.J. (2001) Radiogenic and Stable Isotope Constraints on the Genesis of the Eloise Cu-Au Deposits, Cloncurry District, Northwest Queensland. Economic Geology, 96, 723-742. http://dx.doi.org/10.2113/96.4.723

[6] Muller, R. (1996) Radiogenic Isotope Geology. Physics Today, 49, 60. http://dx.doi.org/10.1063/1.2807660

[7] Panneerselvam, K., Macfarlane, A.W. and Salters, V.J.M. (2012) Reconnaissance Lead Isotope Characteristics of the Blackbird Deposit: Implications for the Age and Origin of Cobalt-Copper Mineralization in the Idaho Cobalt Belt, United States. Economic Geology, 107, 1177-1188. http://dx.doi.org/10.2113/econgeo.107.6.1177

[8] Solomon, M., Gemmell, J.B. and Zaw, K. (2004) Nature and Origin of the Fluids Responsible for Forming the Hellyer 
Zn-Pb-Cu, Volcanic-Hosted Massive Sulphide Deposit, Tasmania, Using Fluid Inclusions, and Stable and Radiogenic Isotopes. Ore Geology Reviews, 25, 89-124. http://dx.doi.org/10.1016/j.oregeorev.2003.11.001

[9] Ahrens, L.H. (1955) Implications of the Rhodesia Age Pattern. Geochimica et Cosmochimica Acta, 8, 1-15. http://dx.doi.org/10.1016/0016-7037(55)90013-2

[10] Mezger, K. and Krogstad, E.J. (1997) Interpretation of Discordant U-Pb Zircon Ages: An Evaluation. Journal of Metamorphic Geology, 15, 127-140. http://dx.doi.org/10.1111/j.1525-1314.1997.00008.x

[11] Tilton, G.R. (1960) Volume Diffusion as a Mechanism for Discordant Lead Ages. Journal of Geophysical Research, 65, 2933-2945. http://dx.doi.org/10.1029/JZ065i009p02933

[12] Wetherill, G.W. (1956) An Interpretation of the Rhodesia and Witwatersrand Age Patterns. Geochimica et Cosmochimica Acta, 9, 290-292. http://dx.doi.org/10.1016/0016-7037(56)90029-1

[13] Goldich, S.S. and Fischer, L.B. (1986) Air-Abrasion Experiments in U-Pb Dating of Zircon. Chemical Geology, 58, 195-215. http://dx.doi.org/10.1016/0168-9622(86)90010-2

[14] Goldrich, S.S. and Mudrey, M.G. (1972) Dilatancy Model for Discordant U-Pb Zircon Ages. In: Tugarinov, A.I., Ed., Contributions to Recent Geochemistry and Analytical Chemistry, Nauka Publishing Office, Moscow, 415-418.

[15] Holmes, A. (1954) The Oldest Dated Minerals of the Rhodesian Shield. Nature, 173, 612-614. http://dx.doi.org/10.1038/173612a0

[16] Silver, L.T. and Deutsch, S. (1961) Uranium-Lead Method on Zircons. Annals of the New York Academy of Sciences, 91, 279-283.

[17] Wasserburg, G.J. (1963) Diffusion Processes in Lead-Uranium Systems. Journal of Geophysical Research, 68, 48234846.

[18] Chew, D.M., Sylvester, P.J. and Tubrett, M.N. (2011) U-Pb and Th-Pb Dating of Apatite by LA-ICPMS. Chemical Geology, 280, 200-216. http://dx.doi.org/10.1016/j.chemgeo.2010.11.010

[19] Thomson, S.N., Gehrels, G.E., Ruiz, J. and Buchwaldt, R. (2012) Routine Low-Damage Apatite U-Pb Dating Using Laser Ablation-Multicollector-ICPMS. Geochemistry, Geophysics, Geosystems, 13, 1. http://dx.doi.org/10.1029/2011GC003928

[20] Allibon, J., Ovtcharova, M., Bussy, F., Cosca, M., Schaltegger, U., Bussien, D., et al. (2011) Lifetime of an Ocean Island Volcano Feeder Zone: Constraints from U-Pb Dating on Coexisting Zircon and Baddeleyite, and 40AR/39AR Age Determinations, Fuerteventura, Canary Islandssp. Canadian Journal of Earth Sciences, 48, 567-592. http://dx.doi.org/10.1139/E10-032

[21] Bayanova, T.B. and Yakovenchuk, V.N. (1994) U-Pb Dating of Baddeleyite and Zircon from Imandrites on the Kola Peninsula. Doklady Earth science sections, 323, 147-150.

[22] de Assis Janasi, V., de Freitas, V.A. and Heaman, L.H. (2011) The Onset of Flood Basalt Volcanism, Northern Parana Basin, Brazil: A Precise U-Pb Baddeleyite/Zircon Age for a Chapeco-Type Dacite. Earth and Planetary Science Letters, 302, 147-153. http://dx.doi.org/10.1016/j.epsl.2010.12.005

[23] Li, Q.-L., Li, X.-H., Liu, Y., Tang, G.-Q., Yang, J.-H. and Zhu, W.-G. (2010) Precise U-Pb and Pb-Pb Dating of Phanerozoic Baddeleyite by SIMS with Oxygen Flooding Technique. Journal of Analytical Atomic Spectrometry, 25, 1107 1113. http://dx.doi.org/10.1039/b923444f

[24] Soderlund, U. (2006) U-Pb Baddeleyite Ages of Meso- and Neoproterozoic Dykes and Sills in Central Fennoscandia: A Review. 5th International Dyke Conference: Dyke Swarms-Time Markers of Crustal Evolution, IDC-5. Rovaniemi, 31 July 2005-3 August 2005, 75-84.

[25] Wahlgren, C.H., Heaman, L.M., Kamo, S. and Ingvald, E. (1996) U-Pb Baddeleyite Dating of Dolerite Dykes in the Eastern Part of the Sveconorwegian Orogen, South-Central Sweden. Precambrian Research, 79, 227-237. http://dx.doi.org/10.1016/0301-9268(95)00094-1

[26] Aleinikoff, J.N., Lack, J.F.S., Lund, K., Evans, K.V., Fanning, C.M., Mazdab, F.K., et al. (2012) Constraints on the Timing of Co-Cu Au Mineralization in the Blackbird District, Idaho, Using SHRIMP U-Pb Ages of Monazite and Xenotime Plus Zircon Ages of Related Mesoproterozoic Orthogneisses and Metasedimentary Rocks. Economic Geology, 107, 1143-1175. http://dx.doi.org/10.2113/econgeo.107.6.1143

[27] Baltybaev, S.K., Levchenkov, O.A., Glebovitskii, V.A., Rizvanova, N.G., Yakubovich, O.V. and Fedoseenko, A.M. (2010) Timing of the Regional Postmigmatitic K-Feldspar Mineralization on the Base of U-Pb Dating of Monazite (Metamorphic Complex of the Northern Ladoga Region). Doklady Earth Sciences, 430, 186-189. http://dx.doi.org/10.1134/S1028334X1002008X

[28] Bose, S., Dunkley, D.J., Dasgupta, S., Das, K. and Arima, M. (2011) India-Antarctica-Australia-Laurentia Connection in the Paleoproterozoic-Mesoproterozoic Revisited: Evidence from New Zircon U-Pb and Monazite Chemical Age Data from the Eastern Ghats Belt, India. Bulletin of the Geological Society of America, 123, 2031-2049. http://dx.doi.org/10.1130/B30336.1 
[29] Dunning, G.R., Macdonald, A.S. and Barr, S.M. (1995) Zircon and Monazite U-Pb Dating of the Doi Inthanon Core Complex, Northern Thailand: Implications for Extension within the Indosinian Orogen. Tectonophysics, 251, 197. http://dx.doi.org/10.1016/0040-1951(95)00037-2

[30] Evans, J. and Zalasiewicz, J. (1996) U-Pb, Pb-Pb and Sm-Nd Dating of Authigenic Monazite: Implications for the Diagenetic Evolution of the Welsh Basin. Earth and Planetary Science Letters, 144, 421. http://dx.doi.org/10.1016/S0012-821X(96)00177-X

[31] Peterman, E.M., Mattinson, J.M. and Hacker, B.R. (2012) Multi-Step TIMS and CA-TIMS Monazite U-Pb Geochronology. Chemical Geology, 312-313, 58-73. http://dx.doi.org/10.1016/j.chemgeo.2012.04.006

[32] Rasmussen, B., Fletcher, I.R. and McNaughton, N.J. (2001) Dating Low-Grade Metamorphic Events by SHRIMP $\mathrm{U}-\mathrm{Pb}$ Analysis of Monazite in Shales. Geology, 29, 963-966. http://dx.doi.org/10.1130/0091-7613(2001)029<0963:DLGMEB>2.0.CO;2

[33] Rasmussen, B., Fletcher, I.R., Muhling, J.R., Mueller, A.G. and Hall, G.C. (2007) Bushveld-Aged Fluid Flow, Peak Metamorphism, and Gold Mobilization in the Witwatersrand Basin, South Africa: Constraints from in Situ SHRIMP U-Pb Dating of Monazite and Xenotime. Geology, 35, 931-934. http://dx.doi.org/10.1130/G23588A.1

[34] Baumgartner, R., Romer, R.L., Moritz, R., Sallet, R. and Chiaradia, M. (2006) Columbite-Tantalite-Bearing Granitic Pegmatites from the Serido Belt, Northeastern Brazil: Genetic Constraints from U-Pb Dating and Pb Isotopes. Canadian Mineralogist, 44, 69-86. http://dx.doi.org/10.2113/gscanmin.44.1.69

[35] Camacho, A., Baadsgaard, H., Davis, D.W. and Cerny, P. (2012) Radiogenic Isotope Systematics of the Tanco and Silverleaf Granitic Pegmatites, Winnipeg River Pegmatite District, Manitoba. Canadian Mineralogist, 50, 1775-1792. http://dx.doi.org/10.3749/canmin.50.6.1775

[36] Melcher, F., Graupner, T., Henjes-Kunst, F., Oberthur, T., Sitnikova, M., Gabler, E., et al. (2008) Analytical Fingerprint of Columbite-Tantalite (Coltan) Mineralisation in Pegmatites-Focus on Africa. 9th International Congress for Applied Mineralogy, ICAM 2008, 8-10 September 2008, Brisbane, 615-624.

[37] Melleton, J., Gloaguen, E., Frei, D., Novak, M. and Breiter, K. (2012) How Are the Emplacement of Rare-Element Pegmatites, Regional Metamorphism and Magmatism Interrelated in the Moldanubian Domain of the Variscan Bohemian Massif, Czech Republic? Canadian Mineralogist, 50, 1751-1773. http://dx.doi.org/10.3749/canmin.50.6.1751

[38] Schmitt, A.K. and Zack, T. (2012) High-Sensitivity U-Pb Rutile Dating by Secondary Ion Mass Spectrometry (SIMS) with an $\mathrm{O}_{2}{ }^{+}$Primary Beam. Chemical Geology, 332-333, 65-73. http://dx.doi.org/10.1016/j.chemgeo.2012.09.023

[39] Essex, R.M. and Gromet, L.P. (2000) U-Pb Dating of Prograde and Retrograde Titanite Growth during the Scandian Orogeny. Geology, 28, 419-422. http://dx.doi.org/10.1130/0091-7613(2000)28<419:UDOPAR>2.0.CO;2

[40] Nesterova, N.S., Kirnozova, T.I. and Fugzan, M.M. (2011) New U-Pb Titanite Age Data on the Rocks from the Karelian Craton and the Belomorian Mobile Belt, Fennoscandian Shield. Geochemistry International, 49, 1161-1167. http://dx.doi.org/10.1134/S0016702911120081

[41] Spencer, K.J., Hacker, B.R., Kylander-Clark, A.R.C., Andersen, T.B., Cottle, J.M., Stearns, M.A., et al. (2013) Campaign-Style Titanite U-Pb Dating by Laser-Ablation ICP: Implications for Crustal Flow, Phase Transformations and Titanite Closure. Chemical Geology, 341, 84-101. http://dx.doi.org/10.1016/j.chemgeo.2012.11.012

[42] Richards, J.P., Cumming, G.L., Krstic, D., Wagner, P.A. and Spooner, E.T.C. (1988) Pb Isotope Constraints on the Age of Sulfide Ore Deposition and U-Pb Age of Late Uraninite Veining at the Musoshi Stratiform Copper Deposit, Central African Copper Belt, Zaire. Economic Geology, 83, 724-741. http://dx.doi.org/10.2113/gsecongeo.83.4.724

[43] Votyakov, S.L., Ivanov, K.S., Khiller, V.V., Bochkarev, V.S. and Erokhin, Y.V. (2011) Chemical Microprobe Th-U$\mathrm{Pb}$ Age Dating of Monazite and Uraninite Grains from Granites of the Yamal Crystalline Basement. Doklady Earth Sciences, 439, 994-997. http://dx.doi.org/10.1134/S1028334X1107018X

[44] Li, X.-H., Li, W.-X., Wang, S.-C., Li, Q.-L., Liu, Y. and Tang, G.-J. (2009) Role of Mantle-Derived Magma in Genesis of Early Yanshanian Granites in the Nanling Range, South China: In Situ Zircon Hf-O Isotopic Constraints. Scientia Sinica Terrae, 39, 872-887. http://dx.doi.org/10.1007/s11430-009-0117-9

[45] Zheng, J.P., Griffin, W.L., Ma, Q., O’Reilly, S.Y., Xiong, Q., Tang, H.Y., et al. (2012) Accretion and Reworking beneath the North China Craton. Lithos, 149, 61-78. http://dx.doi.org/10.1016/j.lithos.2012.04.025

[46] Compston, W., Williams, I.S. and Clement, S.W. (1982) U-Pb Ages within Single Zircons Using a Sensitive High Mass-Resolution Ion Microprobe. The 30th Annual Conference on Mass Spectrometry and Allied Topics, Abstracts, Honolulu, 15 February 1984, B525-B534.

[47] Compston, W., Williams, I.S. and Meyer, C. (1984) U-Pb Geochronology of Zircons from Lunar Breccia 73217 Using a Sensitive High Mass-Resolution Ion Microprobe. Journal of Geophysical Research, 89, 525-534. http://dx.doi.org/10.1029/JB089iS02p0B525

[48] Feng, R., Machado, N. and Ludden, J. (1993) Lead Geochronology of Zircon by Laser Probe-Inductively Coupled Plasma Mass Spectrometry (LP-ICPMS). Geochimica et Cosmochimica Acta, 57, 3479-3486. 
http://dx.doi.org/10.1016/0016-7037(93)90553-9

[49] Srinivasan, G., Whitehouse, M.J., Weber, I. and Yamaguchi, A. (2004) U-Pb and Hf-W Chronometry of Zircons from Eucrite A881467. The 35th Lunar and Planetary Science Conference, League City, TX, 19 March 2004, 1709.

[50] Fong, C.F.C.M., Kee, D.D. and Kaloni, P.N. (2002) Advanced Mathematics for Engineering and Science. World Scientific Publishing Co. Pte. Ltd, Singapore.

[51] Wang, J., Qian, Z., Qian, W., Zhuang, Y., He, Y. and Pan, C. (1999) Analysis of Regression and Variance, in Probability Statistics (Engineering Mathematics). Tongji University, Shanghai, 240-247. (In Chinese)

[52] Bühlmann, P. and Mächler, M. (2008) Computational Statistics, 4-10.

https://stat.ethz.ch/education/semesters/ss2012/CompStat/sk.pdf 


\section{Appendix A: Standard Error (10) for the Slope Using the Least Squares Method}

The least squares method is described in textbooks on probability statistics [51] [52]. For a measured set of val-

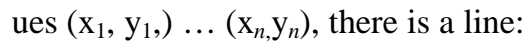

$$
Y=k x+b
$$

that best fits the data. The quality of this line is determined by

$$
Q(k, b)=\sum_{i=1}^{n}\left[y_{i}-\left(k x_{i}+b\right)\right]^{2} .
$$

When $Q(k, b)$ is at its minimum value, the estimation (Equation (A.1)) is the "best" fitting of the measured data. This approach is referred to as the method of linear-least-squares.

To find the minimum value for $Q(k, b)$, the following equation must be solved:

$$
\left\{\begin{array}{l}
\frac{\partial}{\partial b} Q(k, b)=\sum_{i=1}^{n}\left[y_{i}-\left(k x_{i}+b\right)\right](-2)=0 \\
\frac{\partial}{\partial k} Q(k, b)=\sum_{i=1}^{n}\left[y_{i}-\left(k x_{i}+b\right)\right]\left(-2 x_{i}\right)=0
\end{array}\right.
$$

giving

$$
\left\{\begin{array}{l}
k=\frac{\sum_{i=1}^{n}\left(x_{i}-\bar{x}\right)\left(y_{i}-\bar{y}\right)}{\sum_{i=1}^{n}\left(x_{i}-\bar{x}\right)^{2}} \\
b=\bar{y}-k \bar{x}
\end{array}\right.
$$

where $\bar{x}=\sum_{i=1}^{n} x_{i} / n$ and $\bar{y}=\sum_{i=1}^{n} y_{i} / n$. Then Equation (A.1) becomes

$$
\left\{\begin{array}{l}
\bar{k}=\frac{\sum_{i=1}^{n}\left(x_{i}-\bar{x}\right)\left(Y_{i}-\bar{Y}\right)}{\sum_{i=1}^{n}\left(x_{i}-\bar{x}\right)^{2}} \\
\bar{b}=\bar{Y}-k \bar{x}
\end{array}\right.
$$

The variance of a new predicted $Y_{i}$ then follows:

$$
D\left(Y_{i}\right)=\sigma_{Y_{i}}^{2}=\frac{\sum_{i=1}^{n}\left(y_{i}-Y_{i}\right)^{2}}{n}=\frac{1}{n}\left(\sum_{i=1}^{n}\left(y_{i}-\bar{y}\right)^{2}-\frac{\left[\sum_{i=1}^{n}\left(x_{i}-\bar{x}\right)\left(y_{i}-\bar{y}\right)\right]^{2}}{\sum_{i=1}^{n}\left(x_{i}-\bar{x}\right)^{2}}\right),
$$

where $\sigma$ is the standard error of $Y_{i}$ or

$$
D\left(Y_{i}\right)=\sigma_{Y_{i}}^{2}=\frac{\sum_{i=1}^{n}\left(y_{i}-Y_{i}\right)^{2}}{n-2},
$$

if $n$ is very small. Because $k$ follows a Gaussian distribution, its variance is 


$$
\begin{aligned}
D(k) & =\sigma_{k}^{2}=D\left(\frac{\sum_{i=1}^{n}\left(x_{i}-\bar{x}\right) Y_{i}}{\sum_{i=1}^{n}\left(x_{i}-\bar{x}\right)^{2}}\right)=\frac{\sum_{i=1}^{n} D\left\{\left(x_{i}-\bar{x}\right) Y_{i}\right\}}{\left[\sum_{i=1}^{n}\left(x_{i}-\bar{x}\right)^{2}\right]^{2}}=\frac{D\left(Y_{i}\right)}{\sum_{i=1}^{n}\left(x_{i}-\bar{x}\right)^{2}} \\
& =\frac{1}{n-2}\left(\frac{\sum_{i=1}^{n}\left(y_{i}-\bar{y}\right)^{2}}{\sum_{i=1}^{n}\left(x_{i}-\bar{x}\right)^{2}}-\frac{\left[\sum_{i=1}^{n}\left(x_{i}-\bar{x}\right)\left(y_{i}-\bar{y}\right)\right]^{2}}{\left(\sum_{i=1}^{n}\left(x_{i}-\bar{x}\right)^{2}\right)^{2}}\right) .
\end{aligned}
$$

The square root of this equation is the $1 \sigma$ error of $k$. 